\title{
Anti-Criminalization System for Perpetrators of Criminal Acts of Terrorism
}

\author{
M.R. Dayan ${ }^{1} \&$ Doris Padmini Selvaratnam ${ }^{2}$ \\ ${ }^{1}$ Faculty of Law, Universitas Sumatera Utara, Indonesia \\ ${ }^{2}$ Faculty of Economics and Management, Universiti Kebangsaan Malaysia, Malaysia
}

\begin{abstract}
Terrorism is a very serious threat to society, nations, and countries, which requires an anticriminalization system that is not only oriented to extermination in the form of a death sentence as in the current implementation of criminal sanctions for the case in Indonesia. It has been obvious that this is not effective to combat criminal actions by perpetrators of terrorism and wipe out the perpetrators themselves. The efforts of eradicating criminal acts of terrorism in the Indonesian anti-criminalization system have not been oriented to rehabilitation and treatment for the perpetrators as victims of misleading jihad ideology (soft power doctrine). An effective anti-criminalization system oriented to rehabilitation and treatment is expected to be able to minimize crimes related to terrorism. Based on the data of BNPT (National Body for Terrorism Eradication) of the Republic of Indonesia, the 700 people sentenced and 90 people killed in the crime scenes so far have been mostly criminal victims of radicalism, thinking only their own religious belief is true while the others are wrong. These perpetrators do not stop with believing in their faith as they also force other people to follow their view.
\end{abstract}

Keywords: anti-criminalization system, criminal act of terrorism, perpetrator of terrorism, treatment and rehabilitation.

\section{Introduction}

Criminal acts of terrorism can happen anytime with unpredicted targets. They can widely instill fear in society, cause deaths and significant material losses, and also make profound impacts on life as a nation and as a state.

It is important to implement a punishment system for perpetrators of criminal acts of terrorism within the framework of the criminal system (criminal policy) as terrorism acts create the greatest danger to basic human rights and are an extraordinary crime. Romli Atmasasmita says that from a sociological point of view, terrorism is a crime very detrimental to both the national and the international community, and it is even a violation of basic human rights (Atmasasmita, 2004: 3). This is in line with the opinion of Indriyanto Seno Aji (2002) that the consequences of the crime of terrorism, which violate basic human rights, disrupt the economic system, spoil the state's integrity, claim victims of innocent civilians, and damage public facilities, are very significant, and so the perpetrators can be categorized as political offenders with a political purpose to be achieved by violence where the acts are intended to shock or intimidate the government yet victimize the innocent public and create a social impact by way of violence or violent threats, thus arousing fear (Gardner, 1999: 84).

Criminal acts of terrorism can happen anytime in various forms with unpredicted targets. They can widely instill fear in society, cause deaths and significant material losses, and also make profound impacts on life as a nation and as a state. As such, a proper criminal policy is needed in the eradication of criminal acts of terrorism in the Indonesian anti-criminalization system. At the moment the Indonesian legal system does not differentiate between perpetrators who are victims and perpetrators who order the acts so that the terrorism policy is more oriented to punishing by death sentence. The legal handling of terrorism is regulated in Law No. 15 of 2003.

With the existing approach to handling criminal acts of terrorism in Indonesia, the number of crimes related to terrorism remains significant. This shows that the anti-criminalization system for perpetrators of criminal acts of terrorism that is currently applied in Indonesia, which is more oriented to punishment and discouragement, has not been effective. Besides, law enforcement in Indonesia is still oriented to legal certainty based on the order of the laws without good religious faith as a foundation. According Romli Atmasasmita, (2004:12) legal enforcement without good religious faith could result in hypocrisy and injustice, especially injustice to suspects who have not yet been declared guilty by a court verdict that is final and conclusive (Atmasasmita). It is thus understandable that Jeremy Bentham wrote that criminalization shall not be applied or used if it is"groundless, needless, unprofitable or inefficacious" (Arief, 2008:32). 
How criminal acts of terrorism has been handled in a period of 5 years after the passing of Law No. 15 of 2003 can be seen in the following data from Sub-detachment of Investigation of Special Detachment 88 of Indonesian Police:

1. Arrested 900 people

2. Dead in scene 90 people

3. Sentenced 700 people

4. Released 308 people

5. Undergoing imprisonment 392 people

6. Recidivism 25 people.

Based on this background description, issues related to the anti-criminalization system for perpetrators of organized criminal acts of terrorism are formulated.

\section{Discussion}

Terrorism is defined as the use of terror as a symbolic act designed to influence political policies and behaviors through extreme ways, especially using violence and threats of violence. In terrorism, the use of violent ways and causing terror are seen as a legitimate way to achieve objectives. Acts of terrorism have of three elements (Gardner, 1999: 84), namely:

1. Acts or threats of violence.

2. Emotional reactions to extreme fear from the victims or potential victims.

3. Social impacts following the violence or threats of violence as an aftermath.

Terrorism can be defined as the use of or the threat to use physical violence that is planned, prepared, and implemented to a target who is normally a non-combatant to achieve a political purpose. The definition of terrorism in a long formulation by James Adams is: (Ali, 2003: 59.) the use or the threat to use physical violence by individuals or groups with political purposes, either for a certain interest or to fight against the existing authority, which is if the act of terrorism is intended to shock, disable, intimidate a target bigger than the actual victims.

The eradication of criminal acts of terrorism in the framework of an effective anti-criminalization system is essentially intended to cut off the terrorism chain by introducing and correcting the religious teachings through rehabilitation. There are generally three broad groups of theories on criminalization in Indonesian criminal law, namely absolute theory or punishment theory (vergeldings theorien), relative theory or theory of purpose (doel theorien), and combining theory (verenigings theorien). (Presetyo, 2010: 15)

The application of the legal instrument in Law No. 15 of 2003 to eradicate a crime can be seen as a criminal policy, which according to Muladi means a rational effort to eradicate crimes. Such a criminal policy is part of a country's law enforcement policy in its broad meaning, which is a component of its social policy with a purpose of improving its people's welfare (Muladi and Arief, 1992:1)

In line with Muladi's view, Barda Nawawi Arief explains that studying a criminal legal policy is basically studying the problem of how a criminal law should be made, composed, and applied to regulate/control human behaviors, especially to combat crimes to protect people and maintain their welfare (Arief, 2007:7-8).

A proper anti-criminalization system in eradicating criminal acts of terrorism is important to comprehensively prevent the perpetrator from becoming a victim of the crime of terrorism. This is based on the consideration that the concept in the eradication of criminal acts of terrorism as specified in Indonesian laws is vertical in nature, which means it depends on the role of government apparatus such as police, intelligence, and court without using criminalization facilities in the implementation of the anti- and contra-terrorism policy. One of these facilities is rehabilitation for perpetrators as victims of the crime of terrorism.

Rehabilitation for perpetrators of terrorism is important to be realized. In an effort of preventing convicts from returning to extreme radicalism network, rehabilitation and reintegration to society programs must be given to them. Nasir Abbas, for instance, who has been a convict in a terrorism case, states that the root of terrorism problems is the ideology of retaliation with religious justifications. People, be it rich, poor, educated, or uneducated, can be influenced, and this ism cannot be fought with weapons. Therefore, to remove radicalism from inside the perpetrator of terrorism, a soft approach is needed to correct the doctrine they believe to be true.

Law enforcement in the Indonesian criminal justice system shows that rehabilitation is given a narrow meaning. Rehabilitation actually has broad and narrow meanings. The broad meaning of rehabilitation refers to a process where individuals that have violated the law are accepted back as an integral part of their society and assisted to achieve that objective. In its narrow meaning, rehabilitation is defined as the reduction of criminal recidivism for perpetrators of criminal acts. In psychology studies, the use of rehabilitation in its narrow meaning is more common. In criminal justice interventions, there are certain aspects that can maximize the possibility of obtaining practical impacts and that are useful to prevent criminal recidivism. Some of the major 
findings include the discovery that rehabilitative efforts have a higher possibility of success when based on a clear theory regarding perpetrators of criminal acts and having strong empirical supports.

Rehabilitation and social reintegration programs for convicts of terrorism cases aim at cutting off their criminal link through internalization of values during their time in prison. When they return to society, it is so expected that these ex-prisoners will not rejoin their network and perform terrorism acts again. This objective is in line with the objective of criminalization. There are basically three objectives of criminalization, namely: One, to rehabilitate the criminal himself as a person. Two, to discourage people from doing crimes. Three, to render certain criminals, i.e. those somehow unrehabilitable, unable to perform other crimes (Setiady, 2010: 31).

\section{Conclusion}

Efforts are made to optimally eradicate criminal acts of terrorism. The needed approach is using an integrated anti-criminalization system for perpetrators as victims of the crime of terrorism by introducing and correcting the religious teachings through rehabilitation. This is a rational effort to control crimes related to social issues, which can take various forms. Of course we should use not only penal means like death sentences, but also rehabilitation. This means we still need to seek to make a better criminal law, i.e. the one that fulfills the requirements of justice and effectiveness. As for the rehabilitation policy in the framework of eradication of criminal acts of terrorism, it is basically an integral part of the people (social welfare) protection effort. It can be said, then, that the main objective of criminalization should be protecting the people to achieve social welfare.

\section{Acknowledgement}

This paper is presented in Workshop and Coaching on Writing Publication in International Journal (WCWPIJ) 2014, Malaysia. Therefore, the authors express their gratitude to ThinkSmart Scholar (TS Scholar) for the event and the valuable inputs during the preparation and improvement processes of this article.

\section{References}

[1] A. Bryan Gardner, Editor in Chief, 7th Ed. (Black Law Dictionary, 1999).

[2] A.Z. Abidin, Bunga Rampai Hukum Pidana (Jakarta: Pradnya Paramita, 1983).

[3] Barda Nawawi Arief, Kapita Selekta Hukum Pidana Tentang Sistem Peradilan Terpadu (Integrated Criminal Justice System) (Semarang: Badan Penerbit Undip, 2007).

[4] Barda Nawawi Arief, Bunga Rampai Kebijakan Hukum Pidana, Perkembangan Penyusunan Konsep KUHP Baru (Jakarta: Kencana, 2008).

[5] Ediwarman, Monograf Metodologi Penelitian Hukum (Medan, 2009).

[6] E.Y. Kanter \& S.R. Sianturi, Asas-asas Hukum Pidana di Indonesia dan Penerapannya, Cet. I, (Jakarta: Alumni AHM-PTHM, 1982).

[7] G. Pieter Hoefnagels, The Other Side of Criminology: An Inversion of The Concept of Crime (Holland: Kluwer Deventer, 1972).

[8] H. Abdul Manan, Aspek-Aspek Pengubah Hukum (Jakarta: Kencana Prenada Media, 2009).

[9] Hans Kelsen, Pure Theory of Law, translated by Raisul Muttaqien (California: Berkely University of California Press, 1978).

[10] Indriyanto Seno Adji, Permasalahan Terorisme dan Hukum Pidana, the paper was presented in a socialization session of the Draft Law concerning tourism eradication held by the Department of Justice and Human Rights of the Republic of Indonesia, Jakarta, 3 December 2001.

[11] Irfan Idris (Director of Deradicalization Division of the National Body for Terrorism Eradication (BNPT) of the Republic of Indonesia), a Paper entitled Rehabilitasi Mantan Terorisme dan Keluarga, Jakarta, 11 June 2013.

[12] Law No. 15 of 2003 concerning Eradication of Criminal Acts of Terrorism

[13] Lawrence Friedmen, America Law An Introduction, translated by Wisnu Basuki (Jakarta: PT. Tatanusa, 1984).

[14] Muchamad Ali, Syafaat dalam Terorisme, Definisi, Aksi dan Regulasi, (Jakarta: Imparsial, 2003).

[15] Mahmud Mulyadi, Criminal Policy (Medan: Pustaka Bangsa Press, 2010).

[16] Muladi, Penanggulangan Terorisme Sebagai Tindak Pidana Khusus, seminar Pengamanan Terorisme sebagai Tindak Pidana Khusus, Jakarta, 28 January 2004.

[17] Muladi \& Barda Nawawi, Teori dan Kebijakan Pidana (Bandung: Alumni, 1992).

[18] Mustafa Abdullah \& Ruben Achmad, Intisari Hukum Pidana, Cet. I, (Jakarta: Ghalia Indonesia, 1983).

[19] Peter De cruz, Perbandingan Sistem Hukum: Common Law, Civil Law \& Socialist Law, translated by Narulita Yusron (Jakarta: Nusa Bangsa, 2010).

[20] Romli Atmasasmita, Kapita Selekta Hukum Pidana Internasional (Bandung: CV. Utomo, Bandung, 2004).

[21] Regulation in Lieu of Law No. 1 of 2002 concerning Eradication of Criminal Acts of Terrorism.

[22] Soeharto, Implemetasi Perlindungan Hak Tersangka, Terdakwa dan Korban dalam Undang-Undang Nomor 15 Tahun 2003 tentang Pemberantasan Tindak Pidana Terorisme, a thesis paper, Universitas Padjadjaran, Bandung, 2009.

[23] Sunarto, Kriminalisasi Dalam Tindak Pidana Terrorisme, Journal Equality, 12, 2007.

[24] Teguh Presetyo, Hukum Pidana (Jakarta: PT. Raja Grafindo Persada, 2010).

[25] Wina Armada, Wajah Hukum Pidana Pers, Cet. I (Jakarta: Kartini, 1989). 